\title{
Various methods of 3D and Bio-printing
}

\author{
Vukoman Jokanović ${ }^{1,2}$, Božana Čolović2 ${ }^{2}$ Đorđe Antonijević2 ${ }^{2}$ Milutin Mićićc ${ }^{3}$, Slavoljub Živković ${ }^{4}$ \\ ${ }^{1}$ ALBOS d.o.o, Innovative manufacturing enterprise, Belgrade, Serbia; \\ ¿University of Belgrade, Institute of Nuclear Sciences "Vinča", Laboratory for Atomic Physics, Belgrade, Serbia; \\ ${ }^{3} U$ niversity of Belgrade, Institute for Anatomy, Faculty of Medicine, Serbia; \\ «University of Belgrade, School of Dental Medicine, Department for Restorative Dentistry and Endodontics, Belgrade, Serbia
}

\begin{abstract}
SUMMARY
There is growing need for synthetic tissue replacement materials designed in a way that mimic complex structure of tissues and organs. Among various methods for fabrication of implants (scaffolds), 3D printing is very powerful technique because it enables creation of scaffolds with complex internal structures and high resolution, based on medical data sets. This method allows fabrication of scaffolds with desired macro- and micro-porosity and fully interconnected pore network. Rapid development of 3D printing technologies has enabled various applications from the creation of anatomical training models for complex surgical procedures to the printing of tissue engineering constructs. The aim of current investigations was to develop compatible printers and materials (bioinks) to obtain biomimetic scaffolds, which allow printing of living cells without significant loss of cell viability. The advanced level of such printing assumes "in situ" printing, i.e. printing cells and biomaterials directly onto or in a patient that will reduce recovery time. Keywords: 3D printing; bio printing; scaffolds, biomaterials
\end{abstract}

\section{INTRODUCTION}

Tissue engineering strategy typically involves combination of cells and bioactive factors with a 3D scaffold to form useful construct for implantation [1,2]. Ideally, scaffold should be completely resorbed during tissue integration. Biomaterial scaffolds should mimic important aspects of targeted tissue, restoring their function and providing an environment suitable for cell differentiation and proliferation $[3,4]$. Traditional techniques used for production of such scaffolds are gas foaming, solvent casting, fiber bonding, phase separation, particulate leaching, and freeze drying techniques that provide macroscale scaffold features but often lack the complexity of native tissue [5].

Fabrication methods that enable production of complex geometries have significant advantages since they provide production of scaffolds of irregular shape that can perfectly fit the defect geometry. Besides, they can also mimic tissue complexity through precise positioning of multiple materials and cell types. As it is known, scaffolds should provide not only macroscale structural design, but also microscale features necessary for cellular sophisticated control over fabrication of a new tissue. Recently, 3D fabrication or rapid-prototyping technology has become popular and accessible, allowing everyday investigations of potential new fabrication techniques with better geometric accuracy on the macro and micro scale level $[6,7]$. Those investigations have opened door to innumerable approaches of scaffolds engineering such as high-resolution imaging and 3D printing technology known as laser sintering which was successfully used to create functional jawbone replacement [8]. This method has enabled creation of articulated joints, cavities that promote muscle attachment, and grooves to guide nerve and vein regrowth, and also reduced surgical preparation and accelerated recovery. In addition, designed vasculature may enable creation of larger constructs useful for nutrient transport for tissue growth. Functional tissue constructs could also be applied as a diagnostic tool for drug testing or other therapeutic procedures.

Currently used 3D biofabrication printing methods can be divided into acellular techniques which include stereolithography (SLA), powder-fusion printing (PFP) and fused deposition modeling (FDM)), and bioprinting of cellularized constructs that can be inkjet-based, extrusion-based, or laser assisted (LAB)) [8].

\section{ACELLULAR SCAFFOLD FABRICATION}

Rapid prototyping techniques use multi-axis positioning systems and one of various methods to generate a 3D construct through subsequent layer fabrication (extrusion, deposition, solidification, polymerization, sintering or binding using many other methods) $[8,9]$. First step is creating a model in a computer-aided design (CAD) program and export it into the file format that describes the volume or surface mesh in 3D space such as ${ }^{*}$.stl (stereolithography), ${ }^{*}$.obj (object), or ${ }^{*}$.amf (additive manufacturing file). Second step is translation of the 3D data into slices to be patterned by the printer program using the 
program generally known as a 'slicer'. These techniques enable user to configure algorithm that determines pattern used to fill the layers and then the program calculates necessary parameters such as extrusion speed, cure time, or laser speed to accurately fill the pattern.

Previously, these techniques were adapted to mold casting, but recent rapid development increased their versatility and precision. Nowadays techniques are able to create scaffolds that fully mimic macroscale organs geometry and print layers with thickness less than $20 \mu \mathrm{m}$ allowing complete reproduction of the tissue microarchitecture. Techniques with higher precision are currently under investigation to enable reproduction of smaller tissue features such as hepatic lobules and kidney nephrons.

\section{Stereolithography (SLA)}

SLA techniques use deflected laser beam or projected light source to cure and harden given areas of photopolymer at the surface of some material (Figure 1) [8, 10]. Various photopolymers with suitable viscosity and ability to harden can be used in construct creation with SLA. Cooke used SLA to fabricate 3D scaffolds for bone tissue engineering using biodegradable polymers, like diethyl fumarate and polypropylene fumarate [10]. Also, photo-curable ceramic acrylate suspension was used to form a construct of cancellous bone and bone scaffolds using hydroxyapatite [7].

The disadvantage of SLA methods is limited resolution by the diameter of laser beam (about $250 \mu \mathrm{m}$ ), although small-spot laser systems and digital light processing projection produced features of about $70 \mu \mathrm{m}$. These techniques can also be used to design hydrogel scaffolds from natural and synthetic polymers that expand in water and are significantly less rigid than traditional SLA constructs. Hydrogels have become popular as tissue engineering biomaterials due to their high water content and mechanics similar to soft tissue. Some researchers use this technique for creation of 2- hydroxyethyl methacrylate scaffolds using photolithography for formation of patterns from non-swollen prepolymer, which were then hydrated and seeded with cells [11]. SLA has also been used to make molds that are used to cast negative replicas of the printed molds. Chu et al. made printed mold of a mandible generated using CAD program and data from computed tomography imaging. The mold was filled with a hydroxyapatite/acrylate mixture and heated to cure the scaffold [12].

Accordingly, SLA seems to be a versatile and attractive technique for creating tissue-engineering scaffolds because of its precision and increasing availability of biologically relevant photopolymers.

\section{Powder-fusion printing (PFP)}

PFP uses granular materials (plastic, resin, or metal) for printing that are selectively bound together (Figure 2 ) $[8$, 13]. In selective laser sintering-melting (SLS/SLM), plastic or metal granules are sintered together by a laser beam that is directed across the powder bed, to increase local

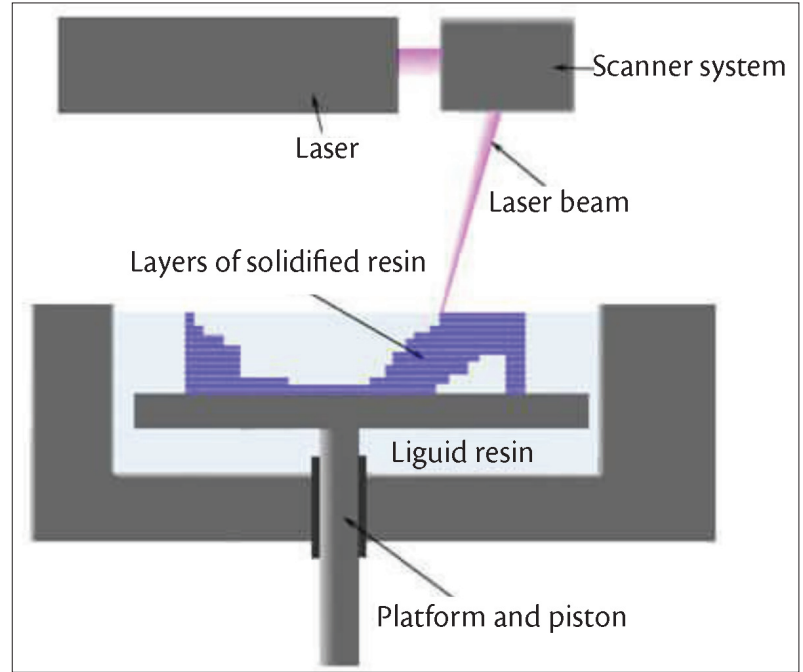

Figure 1. SLA 3D printer used for printing resin-based photopolymers Liquid material solidifies by a high-powered laser or light source, "activating" the photopolymerization reaction. If laser is used to "draw" the object's layers, this method is known as pure SLA. If the method is based on te digital light projection of entire slice of the object this process is known as digital light processing (DLP).

Slika 1. 3D štampač SLA koji se koristi za štampanje fotopolimera na bazi smola

Tečni materijal se očvršćava pomoću laserskog ili svetlosnog izvora velike snage, aktiviranjem reakcije fotopolimerizacije. Ako se koristi laser za "crtanje“ slojeva objekta, ova metoda je poznata kao čista stereolitografija. Ako je metoda zasnovana na projekciji digitalne projekcije čitavog objekta, ovaj proces je poznat kao proces digitalne obrade svetlosti (DLP).

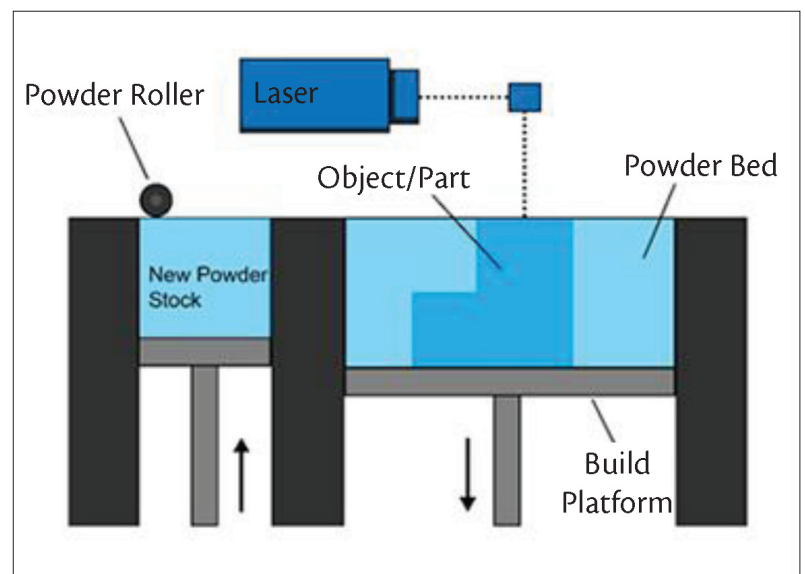

Figure 2. Powder Bed Fusion printer: A layer, typically $0.1 \mathrm{~mm}$ thick material is spread over the built platform, then laser fuses the first layer or first cross section of the model. A new layer of powder is spread across the previous layer using a roller. Further layers or cross sections are fused and added. The process repeats until the entire model is created. Loose, un-fused powder remains in position but is removed during post processing.

Slika 2. Štampač praškastog fuzionog sloja: sloj materijala, tipično debljine $0,1 \mathrm{~mm}$, nanosi se preko platforme, i laserski lepi prvi sloj ili prvi presek modela. Novi sloj praha se širi preko prethodnog sloja pomoću valjka. Dalji slojevi ili preseci se spajaju i dodaju. Proces se ponavlja sve dok se ne kreira ceo model. Neiskorišćeni prah ostaje na poziciji, ali se uklanja kasnije tokom obrade.

temperature influencing particle fusion in the heated area along the laser path. 3D scaffolds are generated by layer-by-layer deposition of the powder. After fabrication, unfused powder is removed and the resulting part is mechanically strong construct with carefully designed geometry and porosity. As in SLA, the resolution of SLS printing depends on the spot size of the laser beam and the size of powder particles. Typical laser-based systems have minimum features of about $400 \mu \mathrm{m}$, with minimum void size of about $50 \mu \mathrm{m}$. SLS techniques have also been developed to fabricate constructs with various biopolymers used in a wide variety of medical implants.

Scaffolds can also be made from granular material by binding the particles with solvents or adhesives whereby 
they are built layer-by-layer. Also, scaffolds can be fabricated from natural biopolymers and polysaccharides like gelatin, dextran, and starch. Microporous structures can be achieved with the addition of porogens and particulate leaching. For example, Simpson et al. fabricated porous poly (lactic-co-glycolic) acid scaffold using PFP and precisely reproduced the shape of an entire human finger phalanx [14]. These porous structures were also investigated from the aspect of cell attachment, growth, and matrix deposition.

Although PFP is limited to powdered materials, its advantage is capability to fabricate scaffolds from several materials such as titanium and magnesium that are not readily printable with other techniques. PFP is particularly suitable for bone and other rigid tissues scaffolds because bound or fused material creates constructs of superior mechanical properties. In addition, some materials naturally found in bone such as tricalcium phosphate can also be printed using PFP techniques, allowing creation of complex scaffold shapes, including in advance designed interconnected porosity. The resolution and minimum pore size are limited by the powder characteristics, and additional sintering is necessary to solidify parts that contain cracks and other damages. The focus of current research is on developing new materials for PFP and refinement of printing parameters to improve scaffold surface design.

\section{Fused deposition modeling (FDM)}

FDM techniques enable useful platform for scaffolds creation by using precise xyz positioning system to direct the position of a nozzle during material deposition $[8,15]$. The material is deposited in layers and solidified into a previously defined shape. Traditional SFF printers are frequently used for rapid prototyping by using a small diameter polymer feedstock of acrylonitrile butadiene styrene which is forced through the nozzle heated to temperatures higher than $200^{\circ} \mathrm{C}$.

Biodegradable polymers used in tissue engineering typically melt at lower temperatures and can be printed at more moderate temperatures $\left(60-100{ }^{\circ} \mathrm{C}\right)$. Using this method it is possible to produce precise lattice structure, if temperature is precisely controlled and optimized with speed parameters during generation of filament with required accuracy. Newer generations of FDM systems use heated reservoir for extrusion of polymer pellets rather than fibers. Scaffolds produced by this technique from alginate and PCL implanted in mice have shown enhanced cartilage and collagen formation over a 4-week implantation [8].

Decreasing nozzle size and layer height increases $x-y$ and $\mathrm{z}$ resolution, leading to significantly slower extrusion rates. Theoretical resolution is limited by the precision of the linear motion system (motors, gears, timing belts, and leadscrews) and retention properties of extruded material. Although FDM techniques enable the achievement of high degree of positional accuracy in the xy plane, their substantial limitation is in disability to print overhanging or unsupported parts because there is no supporting

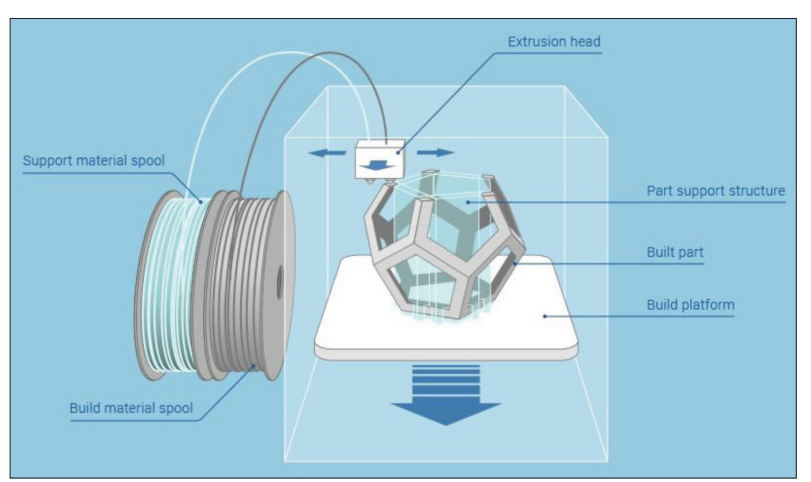

Figure 3. Sheme of fused deposition modelling technique (source: www.additively.com) Slika 3. Šema procesa fuzione depozicije (izvor: www.additively.com)

material from previous layers. Therefore, hardening during cooling or cross-linking after extrusion is essential for satisfied support of subsequent layers. Also, this drawback can be solved with introducing filament of support material during the process of printing, usually through additional extruder (Figure 3 ).

Recent improvements in hydrogel rheological properties enable printing of these materials using FDM. For example, Hong et al. created printable hydrogel using a network of PEG and alginate with silicate nano-platelets [16]. These gels possessed zero-shear viscosity above 10 $\mathrm{kPa} \cdot \mathrm{s}$, enabling shape retention after printing and a shear thinning that facilitated extrusion. The size and accuracy of printed hydrogel construct are dependent on the volume contained in the syringe and rheological properties of the hydrogel. Viscosity plays a key role in construct accuracy, because high-viscosity materials possess structural rigidity that is important for support of extruded successive layers, and secondary cross-linking step is typically used to lock the printed shape and improve mechanical properties of these constructs.

Extrusion-based printers typically use pneumatic pressure or a motor actuated plunger for material deposition. Pneumatic systems simplify control of the applied force to extruded material. The system should be calibrated for each material with adjustments of the nozzle size, nozzle geometry (tapered tip, cylindrical needle, and length), and gas pressure.

FDM seems to be one of the most versatile printing techniques for creation of biomimetic scaffolds due to its ability to make multilayered constructs built from various materials and print soft biomaterials like hydrogels (Figure 4). Scaffolds printed by this technique may exhibit anisotropic mechanical properties that can be useful for creating scaffolds with intended alignment such as ligament or tendon.

\section{BIOPRINTING}

Bioprinting belongs to additive manufacturing techniques for creation of the cell-based scaffolds [17]. These techniques are presumably adapted for printing with cells at the same time as material, since they have minimal impact on the cell viability and function. Biological materials used for printing should match natural environment 


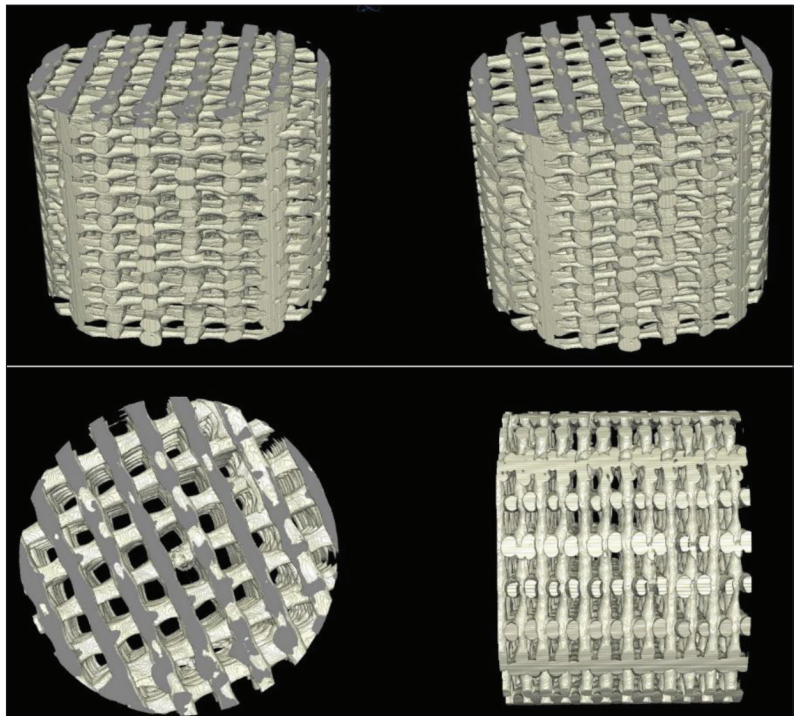

Figure 4. Micro CT volume reconstruction, example of porous bone scafold structure, cilinder of $10 \mathrm{~mm}$ in hight and $10 \mathrm{~mm}$ diameter. Cilinder is made by extrusion printing (FDM) and has ideal porosity, trabecular thickness, pore diameter and connectivity of pores for bone scafold model.

Slika 4. Mikro CT zapreminska rekontrukcija, primer poroznog koštanog skafolda, visine $10 \mathrm{~mm}$ i prečnika $10 \mathrm{~mm}$. Cilindar je napravljen ekstruizonim štampanjem (FDM) i ima idealnu poroznost, trabekularnu debljinu, prečnik pora i povezanost pora, kao skafold za koštano tkivo.

of the host tissue to support function of those cells. Additionally, cells should be able to overcome shear stress during the printing process and survive in real non-physiological conditions of the printing regime [8].

Bioprinting techniques are classified into the three categories: microextrusion, lasser-assisted bioprinting $(\mathrm{LAB})$ and inkjet-based bioprinting. Among them, inkjet bioprinting is the most promising for the creation of complex architectures, successfully mimicking native tissue and organs. In inkjet-bioprinting, bioink droplets are deposited onto the substrate that gels to form polymeric structures, while microextrusion bioprinting uses mechanical extruder to deposit bioink. Additionally, extrusion-bioprinting is useful for high cell density, due to its easier processing, but it is a slower than drop-based bioprinting. $\mathrm{LAB}$ requests a picoliter $(\mathrm{pL})$ resolution through which cells and liquid materials can be printed. This printing method is rapidly growing and it is promising for the fabrication of tissue-like constructs.

\section{Extrusion bioprinting}

Extrusion-bioprinting is one of the most economical techniques for rapid prototyping (Figure 5) $[8,17]$. It typically includes pressure or screw/plunger-actuated dispensing of a fluid containing cells and/or biomaterials. It should provide shear thinning enabling minimal resistance under flow and quick chemical or physical cross-link after extrusion to support successive layers. This technique allows accurate deposition of the material and fabrication of complex patterned structures, including the use of multiple cell types, enabling accelerated growth and new tissue formation. Increasing print resolution and print speed are desirable in extrusion-bioprinting. Additionally, by the modification of printing mechanics, printing time

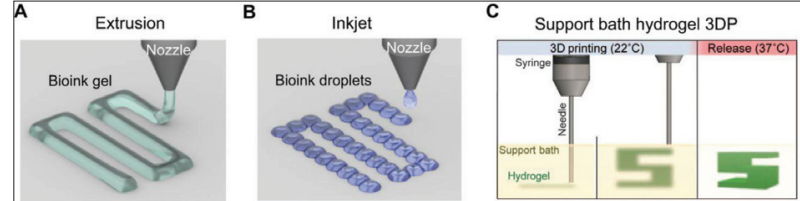

Figure 5. Extrusion-based 3D bioprinting

(A) For extrusion-based bioprinting, material is selectively guided onto a platform via pressurized emission through the nozzle. The material, or 'bioink', is composed of an ECM-like biomaterial, cells and soluble factors.

(B) For inkjet-based bioprinting, droplets of bioink are distributed across a surface to form a patterned layer.

(C) For support bath hydrogel 3DP, biomaterial is extruded into the support hydrogel material. At $22^{\circ} \mathrm{C}$, the hydrogel bath is stable enough to support the extruded print material, but at $37^{\circ} \mathrm{C}$, the hydrogel bath transitions into the more liquid state to release the 3D printed object. The support bath allows formation of complex structures.

Slika 5. Ekstruziono 3D bio-štampanje

(A) Za ekstruziono bio-štampanje materijal se selektivno usmerava na platformu putem emitovanja pritiska kroz mlaznicu. Materijal, ili 'bioink', sastoji se od biomaterijala sličnih ECM-u, ćelija i rastvornih faktora.

(B) Za bio-štampanje na bazi inkdžeta kapljice bioinka se raspoređuju preko površine kako bi se formirao sloj.

(C) Za hidrogelom potpomognuto 3DP biomaterijal se ekstrudira u pomoćni hidrogel. $\mathrm{Na}$ $22^{\circ} \mathrm{C}$ hidrogelno kupatilo je dovoljno stabilno da podrži ekstrudirani štampani materijal, ali na $37^{\circ} \mathrm{C}$ hidrogelno kupatilo prelazi u tečno stanje da oslobodi 3D štampani predmet. Pomoćno kupatilo omogućava formiranje složenih struktura.

can be diminished and coextrusion of multiple materials can be permitted. The main disadvantage is relatively long fabrication time to achieve high resolution in complex structures. This method enables successful fabrication of clinically relevant scaffolds for tissue engineering, because it is ideally adjusted for biological materials due to its ability to deposit multiple materials with wide-ranging properties. Extrusion bioprinted scaffolds are typically soft, due to their high water content that makes them limited to soft tissues application.

\section{Laser-assisted bioprinting (LAB)}

LAB, or biological laser printing, is a group of laser techniques that use laser energy to facilitate densification of scaffold materials (Figure 6) [8,17]. One type of LAB uses laser pulse (laser based direct writing (LDW)) for local heating a slide with an energy-absorbing layer and solution of cells. The laser pulse induces sublimation or evaporation of material, expelling the solution of cells on the opposite side and precisely depositing them on the substrate. This method includes laser-induced forward transfer and matrix-assisted pulsed laser evaporation, which can be used for deposition of fibroblasts, keratinocytes, human mesenchymal stem cells, various cancer cells and biopolymers.

As lasers technique allows high precision, this method is suitable for bioprinting of the smallest details of native tissues and organs. This technique allows direct printing of cells, but with several limitations, like detrimental effect on cell survival and their long-term behavior.

\section{Inkjet bioprinting}

Inkjet bioprinting enables precious deposition of cells and biomaterials, using some advances of $2 \mathrm{D}$ inkjet printing to create $3 \mathrm{D}$ scaffolds $[8,18]$. In this method a limited volume of fluid is falling into the precise pattern specified by the corresponding software. One of the most important 


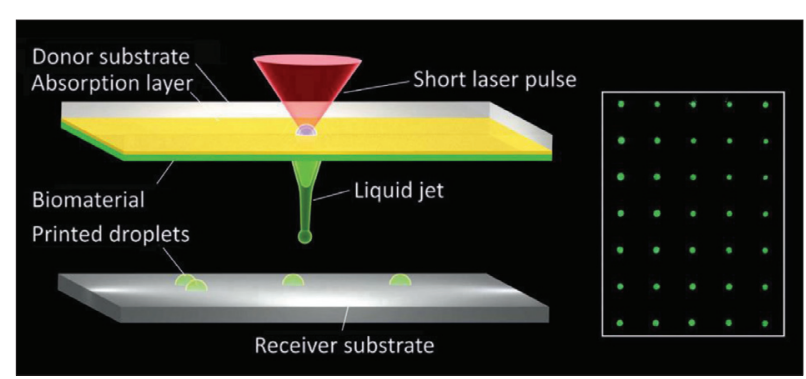

Figure 6. Laser printing of vital cells embedded in hydrogel. The focused laser pulses evaporate an absorption layer locally. The vapor pressure propels the subjacent biomaterial as a liquid jet toward the receiver substrate. The jet lasts for a few hundred microseconds and remains a droplet. The microscopic image (right) shows droplets with fluorescent cells. Slika 6. Lasersko štampanje vitalnih ćelija umetnutih u hidrogel. Fokusirani laserski puls dovodi do lokalnog isparavanja apsorpcionog sloja. Pritisak pare propagira donji biomaterijal kao mlaz tečnosti prema supstratu prijemniku. Taj mlaz traje nekoliko stotina mikrosekundi i ostaje kapljica. Mikroskopska slika (desno) pokazuje kapljice sa fluorescentnim ćelijama.

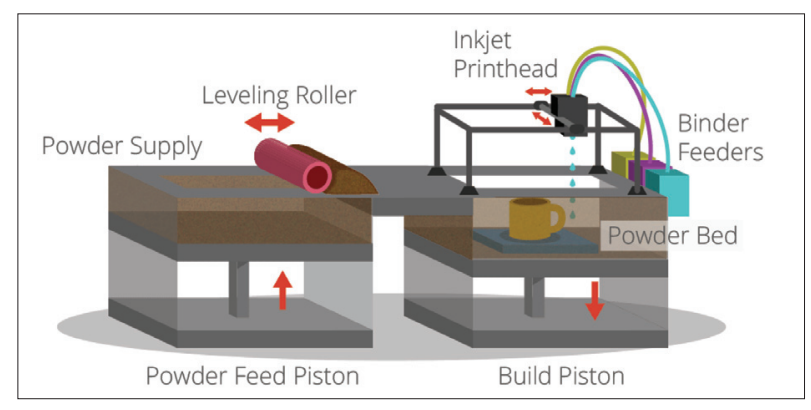

Figure 7. A binder is firstly jetted and selectively sprayed into a powder bed. When one layer is printed, the powder bed drops incrementally and a roller or blade applies and flattens the powder over the surface of the bed, prior to the next pass of the jet heads, with the binder for the subsequent layer to be formed and fused with the previous layer.

Slika 7. Vezivno sredstvo se prvo izbacuje kroz mlaznicu i selektivno prska na rezervoar praha. Kada se odštampa jedan sloj, rezervoar praha postepeno opada, a valjak ili sečivo poravnava prah pre sledećeg prolaza mlaznih glava, sa vezivnim sredstvom za sledeći sloj koji se formira i kondenzuje sa prethodnim slojem.

advantages of this technique is the speed at which it can construct scaffolds with complex $3 \mathrm{D}$ architecture. This high speed limits the number of polymeric materials that can be used for bio-printing, since their gelation time has to be greater or equal to the drop deposition time.

Inkjet bio-printers can be adjusted to print materials at increased resolutions and speeds. They use thermal or piezoelectric energy to deposit droplets of solution into desired patterns and consist of one or many ink chambers with multiple nozzles with corresponding piezoelectric or heating components. A short pulse of current is used to actuate the component and eject a droplet of ink. In thermal bio-printers, there is often a strong increase of temperature in local spots, inducing formation of vapor bubbles and collapsing, leading to ejecting ink droplets onto the substrate. In piezoelectric inkjet printing, piezocrystals induce pressure increase, which further influence the droplet ejection. Deposition from the nozzle onto the printing surface happens when an electric charge induces vibration in the crystals, and vibration propagates to printing surface. It has been shown that heat and mechanical stresses during thermal bioprinting cause decrease of cell viability. Some researchers use this method for printing of retinal ganglion and glia cells isolated from adult central nervous system without causing an adverse effect on cell viability, while some of them succeeded in use of thermo-sensitive gels by modifying cartridge of commercially available inkjet printer to create multilayered scaffolds [8].

The main disadvantage of inkjet printing is request for biological agents to be in a liquid state, to allow deposition. Deposited droplets then solidify into the required geometry, through cross-linking based on physical, chemical, $\mathrm{pH}$, or ultraviolet methods. Due to chemical cross-linking, many natural materials frequently change their chemical properties. In addition, some cross-linking mechanisms induce decrease of cell viability and functionality (Figure 7).

Although inkjet bioprinting enables encapsulation of live cells, their concentration has to be relatively low in order to form cohesive droplets and prevent clogging of the nozzle. Despite numerous disadvantages, this method has a great potential due to its low cost, high resolution, and high compatibility with many biomaterials. Additionally, these printers enable accurate deposition of fine droplets with precise volume to create high-resolution scaffolds with cells intact. Droplet size can be modulated from 1 to $300 \mathrm{pL}$ with deposition rates from 1 to 10,000 droplets per second. Therefore, this method enables scaffolds creation with accuracy within $100 \mu \mathrm{m}$, which is very promising for creating complex scaffolds. Although it cannot produce very tall structures, influenced by the typical mechanical properties of the gel inks, due to its ability to print multiple structures and cell types it is very convenient for printing complex tissues with great accuracy.

\section{INSTEAD OF CONCLUSION: EXPECTED FATE OF THESE METHODS IN THE FUTURE}

Adaptation of current 3D printing methods for biological applications has enormous importance for future fabrication of tissue grafts and artificial organs. Besides tissue engineering, 3D printing is also used in the area of drug delivery, analysis of chemical and biological agents and organ-on-a-chip devices [19].

Despite its huge potential in regenerative strategies, the main challenges are related to necessity of improved resolution, increased speed and printing that enables cells survival [18]. Current efforts in improvement of printing resolution in lithography assume the development of methods like electron beam lithography and multi-photon absorption polymerization, because these methods are suitable for creation of scaffolds with extremely precise feature sizes, of the order of only of tens of nanometers [20].

Materials used for 3D bioprinting must meet the following criteria: should be biocompatible, support cell growth and differentiation and retain its shape long enough to preserve scaffold integrity until solidification locks in scaffold geometry. The most commonly used materials for such purposes are collagen, gelatin, hyaluronic acid, alginate, modified copolymers, and photo-polymerizablemacromers [21].

For design of complex scaffolds that mimic tissue, additional research is necessary for accurate mapping of complex tissues to be able to make well-reproduced scaffolds with required structures and biological properties. One of the main challenges in future in $3 \mathrm{D}$ printing is 
direct ,in situ” bioprinting, or printing cells and biomaterials directly onto or in a patient. Some recent research showed capabilities of bioprinting directly into wounds or burn defects [22]. Further improvements of the printing speed and resolution are needed for ,in situ” printing that will enhance tissue regeneration and reduce patients recovery time.

\section{REFERENCES}

1. Amini AR, Laurencin CT, Nukavarapu SP. Bone Tissue Engineering: Recent Advances and Challenges. Crit Rev Biomed Eng. 2012; 40(5):363-408. [PMID: 23339648]

2. Li J), Kaplan DL, Zreiqat H. Scaffold-based regeneration of skeletal tissues to meet clinical challenges. J Mater Chem B Mater Biol Med. 2014; 2(42):7272-306. [DOl: 10.1039/c4tb01073f]

3. Jokanović V, Čolović B, Marković D, Petrović M, Soldatović I, Antonijević D, et al. Extraordinary biological properties of a new calcium hydroxyapatite/poly(lactide-co-glycolide)-based scaffold confirmed by in vivo investigation. Biomed Tech. 2017; 62(3):295306. [DOI: 10.1515/bmt-2015-0164] [PMID: 27285125]

4. Hutmacher DW. Scaffolds in tissue engineering bone and cartilage. Biomaterials. 2000; 21(24):2529-43. [DOI: 10.1016/S01429612(00)00121-6] [PMID: 11071603]

5. Zhu N, Chen X. Biofabrication of Tissue Scaffolds. In: Pignatello R, editor. Advances in Biomaterials Science and Biomedical Applications. Rijeka: InTech; 2013. [DOI: 10.5772/54125]

6. Ventola CL. Medical Applications for 3D Printing: Current and Projected Uses, Pharmacy and Therapeutics. P T. 2014; 39(10):704-11. [PMID: 25336867]

7. Leukers B, Gülkan H, Irsen SH, Milz S, Tille C, Schieker M, et al. Hydroxyapatite scaffolds for bone tissue engineering made by 3D printing. I Mater Sci Mater Med. 2005; 16(12):1121-4. [DOI: 10.1007/s10856-005-4716-5] [PMID: 16362210]

8. Sears NA, Seshadri DR, Dhavalikar PS, Cosgriff-Hernandez E. A Review of Three-Dimensional Printing in Tissue Engineering. Tissue Eng Part B Rev. 2016; 22(4):298-310. [DOI: 10.1089/ten. teb.2015.0464] [PMID: 26857350]

9. Peltola SM, Melchels FP, Grijpma DW, Kellomäki M. A review of rapid prototyping techniques for tissue engineering purposes. Ann Med. 2008; 40(4):268-80. [DOl: 10.1080/07853890701881788] [PMID: 18428020]

10. Cooke MN, Fisher JP, Dean D, Rimnac C, Mikos AG. Use of stereolithography to manufacture critical-sized 3D biodegradable scaffolds for bone ingrowth. J Biomed Mater Res B Appl Biomater. 2003; 64(2):65-9. [DOI: 10.1002/jbm.b.10485] [PMID: 12516080]
11. Yu T, Ober CK. Methods for the topographical patterning and patterned surface modification of hydrogels based on hydroxyethyl methacrylate. Biomacromolecules. 2003; 4(5):1126-31. [DOl: 10.1021/bm034079m] [PMID: 12959574]

12. Chu TM, Hollister SJ, Halloran JW, Feinberg SE, Orton DG. Manufacturing and characterization of 3-D hydroxyapatite bone tissue engineering scaffolds. Ann N Y Acad Sci. 2002; 961:114-7. [PMID: 12081877]

13. Yang S, Leong KF, Du Z, Chua CK. The Design of Scaffolds for Use in Tissue Engineering. Part II. Rapid Prototyping Techniques. Tissue Eng. 2002; 8(1):1-11. [DOI: 10.1089/107632702753503009] [PMID: 11886649]

14. Simpson RL, Wiria FE, Amis AA, Chua CK, Leong KF, Hansen UN, et al. Development of a 95/5 poly(L-lactide-co-glycolide)/ hydroxylapatite and beta-tricalcium phosphate scaffold as bone replacement material via selective laser sintering. J Biomed Mater Res B Appl Biomater. 2008; 84(1):17-25. [DOI: 10.1002/jbm.b.30839] [PMID: 17465027]

15. Zein I, Hutmacher DW, Tan KC, Teoh SH. Fused deposition modeling of novel scaffold architectures for tissue engineering applications. Biomaterials. 2002; 23(4):1169-85. [DOI: 10.1016/S01429612(01)00232-0] [PMID: 11791921]

16. Hong S, Sycks D, Chan HF, Lin S, Lopez GP, Guilak F, et al. Printing of Highly Stretchable and Tough Hydrogels into Complex, Cellularized Structures. Adv Mater. 2015; 27(27):4035-40. [DOI: 10.1002/ adma.201501099] [PMID: 26033288]

17. Kang HW, Lee SJ, Ko IK, Kengla C, Yoo J), Atala A. A 3D bioprinting system to produce human-scale tissue constructs with structural integrity. Nat Biotechnol. 2016; 34(3):312-9. [DOI: 10.1038/nbt.3413] [PMID: 26878319]

18. Murphy SV, Atala A. 3D bioprinting of tissues and organs. Nat Biotechnol. 2014; 32(8):773-85. [DOl: 10.1038/nbt.2958] [PMID: 25093879]

19. Low KH, Leong KF, Chua CK, Du ZH, Cheah CM. Characterization of SLS parts for drug delivery devices. Rapid Prototyp J. 2001; 7(5):262-8. [DOI: 10.1108/13552540110410468]

20. Linjie L, Fourkas JT. Multiphoton polymerization. Materials Today. 2007; 10(6):30-7. [DOI: 10.1016/S1369-7021(07)70130-X]

21. Gross BC, Erkal JL, Lockwood SY, Chen C, Spence DM. Evaluation of 3D Printing and Its Potential Impact on Biotechnology and the Chemical Sciences. Anal Chem. 2014; 86(7):3240-53. [DOl: 10.1021/ ac403397r] [PMID: 24432804]

22. Skardal A, Mack D, Kapetanovic E, Atala A, Jackson JD, Yoo J, et al. Bioprinted amniotic fluid-derived stem cells accelerate healing of large skin wounds. Stem Cells Transl Med. 2012; 1(11):792-802. [DOI: 10.5966/sctm.2012-0088] [PMID: 23197691] 


\title{
Različite metode 3D štampanja i bio-štampanja
}

\author{
Vukoman Jokanović ${ }^{1,2}$, Božana Čolović2, Đorđe Antonijević², Milutin Mićić3, Slavoljub Živković ${ }^{4}$ \\ ${ }^{1}$ ALBOS d.o.o., inovativno preduzeće za proizvodnju, Beograd, Srbija; \\ Univerzitet u Beogradu, Institut za nuklearne nauke „Vinča“, Laboratorija za atomsku fiziku, Beograd, Srbija; \\ ${ }^{3}$ Univerzitet u Beogradu, Institut za anatomiju, Medicinski fakultet, Beograd, Srbija; \\ ${ }^{4}$ Univerzitet u Beogradu, Stomatološki fakultet, Klinika za restaurativnu stomatologiju i endodonciju, Beograd, Srbija
}

\begin{abstract}
KRATAK SADRŽAJ
Danas postoji sve veća potreba za sintetičkim materijalima za zamenu tkiva dizajniranih na način koji imitira složenu strukturu tkiva i organa. Među različitim metodama proizvodnje implantata (skafolda), 3D štampanje je veoma moćna tehnika jer omogućava kreiranje skafolda sa složenim unutrašnjim strukturama i visokom rezolucijom, zasnovanim na medicinskim skupovima podataka. Ova metoda omogućava proizvodnju skafolda sa željenom makroporoznošću i mikroporoznošću i potpuno povezanom mrežom pora. Brzi razvoj tehnologija 3D štampanja omogućio je različite primene - od kreiranja anatomskih modela za uvežbavanje složenih hirurških procedura do štampanja konstrukata za tkivno inženjerstvo. Cilj tekućih istraživanja je razvoj kompatibilnih štampača i materijala (bio-mastila) za dobijanje biomimičnih skafolda, koji omogućavaju štampanje živih ćelija bez značajnog gubitka njihove vijabilnosti. Napredni nivo takvog štampanja pretpostavlja štampanje in situ, tj. štampanje ćelija i biomaterijala direktno na pacijentu ili u pacijenta, što će smanjiti vreme oporavka.

Ključne reči: 3D štampanje; bioštampanje; skafold; biomaterijali
\end{abstract}

\section{UVOD}

Strategija tkivnog inženjerstva obično podrazumeva kombinaciju ćelija i bioaktivnih faktora i 3D skafolda kako bi se dobio koristan implant $[1,2]$. Idealno, skafold treba da se potpuno resorbuje tokom integracije tkiva. Skafoldi izgrađeni od biomaterijala treba da imitiraju važne aspekte ciljnog tkiva, obnavljaju njihove funkcije i obezbeđuju okruženje pogodno za diferencijaciju i proliferaciju ćelija [3,4]. Tradicionalne tehnike koje se koriste za proizvodnju takvih skafolda su gasna pena, livenje rastvarača, vezivanje vlaknima, fazno odvajanje, čišćenje čestica i tehnike zamrzavanja, koji obezbeđuju makroskopsku strukturu skafolda, ali često nemaju osobenosti prirodnog tkiva [5].

Metode koje omogućavaju dobijanje složenih geometrija imaju značajne prednosti jer omogućavaju proizvodnju skafolda nepravilnog oblika koji se savršeno uklapaju u geometriju defekta. Pored toga, mogu da imitiraju složenost tkiva kroz precizno pozicioniranje višestrukih materijala i tipova ćelija. Kao što je poznato, skafoldi treba da obezbede ne samo makroskopski strukturni dizajn već i mikroskopske karakteristike potrebne za sofisticiranu ćelijsku kontrolu nad formiranjem novog tkiva. Odskora je 3D tehnologija ili tehnologija brzih prototipova postala veoma popularna i pristupačna, omogućavajući svakodnevna istraživanja potencijalnih novih tehnika izrade sa boljom geometrijskom preciznošću na makroskali i mikroskali $[6,7]$. Ova istraživanja otvaraju vrata bezbrojnim pristupima inženjerstva skafolda, kao što je snimanje sa visokom rezolucijom i tehnologija 3D štampanja poznata pod nazivom lasersko sinterovanje, koja se uspešno koristi kao funkcionalna zamena za viličnu kost [8]. Ova metoda je omogućila formiranje zglobova, šupljina koje promovišu vezivanje mišića i žlebova za vođenu regeneraciju nerava i vena, a takođe su smanjili potrebu za hirurškom pripremom i ubrzali oporavak. Pored toga, dizajnirana vaskularna mreža može omogućiti stvaranje većih konstrukcija korisnih za transport hranljivih materija za rast tkiva. Funkcionalne konstrukcije tkiva mogu se takođe primeniti kao dijagnostički alat za testiranje lekova ili za druge terapijske procedure.

Trenutno korišćene metode štampanja mogu se podeliti na acelularne tehnike, koje uključuju stereolitografiju (SLA), štampanje fuzijom praha (PFP) i fuzionu depoziciju (FDM), i bio-štampanje ćelijskih konstrukcija, koje može biti na principu inkdžet, ekstruzije ili potpomognuto laserom (LAB) [8].

\section{ACELULARNE METODE ZA DOBIJANJE SKAFOLDA}

Tehnike brzog prototipovanja koriste višeosne sisteme za pozicioniranje i jednu od različitih metoda za generisanje 3D konstrukcija kroz sukcesivnu izradu slojeva (deponovanje ekstruzijom, očvršćavanje, polimerizacija, sinterovanje ili vezivanje koristeći mnoge druge metode) [8,9]. Prvi korak je kreiranje modela u kompjuterskom programu (CAD) i prebacivanje $\mathrm{u}$ format datoteke koji opisuje površinu ili mrežnu površinu u 3D prostoru kao što su *.stl (stereolitografija), ${ }^{*}$.obj (objekat), ili *.amf (aditivno proizveden fajl). Drugi korak je pretvaranje 3D podataka u „kriške“ koje će biti precrtane od strane programa za štampač, što se obavlja pomoću programa poznatog kao „slicer“. Ove tehnike omogućavaju korisniku da konfiguriše algoritam koji određuje šablon koji se koristi za popunjavanje slojeva, a zatim program izračunava potrebne parametre kao što su brzina ekstruzije, vreme sušenja ili brzina lasera kako bi se tačno popunio šablon.

Prethodno su ove tehnike bile prilagođene za livenje kalupa, ali je nedavni brzi razvoj povećao njihovu svestranost i preciznost. Uz pomoć današnjih tehnika mogu se dobiti skafoldi koji u potpunosti imitiraju makroskopsku geometriju organa i štampati slojevi debljine manje od $20 \mu \mathrm{m}$, što omogućava potpunu reprodukciju mikroarhitekture tkiva. Tehnike sa većom preciznošću trenutno se intenzivno istražuju kako bi se omogućila reprodukcija manjih tkivnih formacija, kao što su hepatični lobuli i bubrežni nefroni.

\section{Stereolitografija}

SLA tehnike koriste skrenuti laserski zrak ili projektovani izvor svetlosti za očvršćavanje datih područja fotopolimera na površini nekog materijala (Slika 1) $[8,10]$. Razni fotopolimeri sa odgovarajućim viskozitetom i sposobnošću očvršćavanja mogu 
se koristiti za pravljenje konstrukata sa SLA. Kuk je koristio SLA za izradu 3D skafolda za inženjerstvo koštanog tkiva koristeći biorazgradive polimere, kao što su dietil-fumarat i poli(propilen fumarat) [10]. Takođe, fotostabilna keramička akrilatna suspenzija je korišćena da se formira konstrukcija šuplje kosti i koštanih skafolda korišćenjem hidroksiapatita [7].

Nedostatak SLA metoda je taj što je rezolucija ograničena prečnikom laserskog zraka (oko $250 \mu \mathrm{m}$ ), iako su laserski sistemi sa malim spotom i digitalna projekcija obrade svetlosti proizveli detalje veličine oko $70 \mu \mathrm{m}$. Ove tehnike se takođe mogu koristiti za dizajniranje skafolda od hidrogelova prirodnih i sintetičkih polimera koji bubre u vodi i znatno su manje kruti od tradicionalnih SLA konstrukata. Hidrogelovi su postali veoma popularni kao biomaterijali u inženjerstvu tkiva zbog visokog sadržaja vode i mehanike slične mekim tkivima. Neki istraživači su koristili ovu tehniku za dobijanje 2-hidroksietilmetakrilatnih skafolda koristeći fotolitografiju za formiranje šablona iz nenabubrenog prepolimera, koji su zatim hidrirani i zasejani ćelijama [11]. SLA se takođe koristi za izradu kalupa koji se koriste za livenje negativnih replika odštampanih kalupa. Ču i saradnici su napravili štampani kalup mandibule, generisan pomoću programa CAD i podataka sa snimanja računarskom tomografijom. Kalup je napunjen mešavinom hidroksiapatita i akrilata i zagrejan da bi se formirao skafold [12].

Shodno tome, izgleda da je SLA svestrana i atraktivna tehnika za dobijanje skafolda za inženjerstvo tkiva zbog svoje preciznosti i povećane dostupnosti biološki relevantnih fotopolimera.

\section{Štampanje fuzijom praha}

PFP koristi granularni materijal (plastika, guma, ili metal) za štampanje, koji se selektivno vezuje zajedno (Slika 2) $[8,13]$. Kod selektivnog laserskog sinterovanja-topljenja (SLS/SLM), plastične ili metalne granule su sinterovane zajedno pomoću laserskog zraka koji je usmeren preko praha, da bi se povećala lokalna temperatura koja utiče na fuziju čestica u zagrejanom području duž puta lasera. 3D skafoldi se generišu nanošenjem praha sloj po sloj. Nakon izrade neiskorišćeni prah se uklanja, a rezultat je mehanički jaka konstrukcija sa pažljivo dizajniranom geometrijom i poroznošću. Kao i kod SLA, rezolucija SLS štampanja zavisi od veličine spota laserskog zraka i veličine čestica praha. Tipični laserski sistemi imaju minimalne karakteristike od oko $400 \mu \mathrm{m}$, sa minimalnom veličinom pora od oko $50 \mu \mathrm{m}$. SLS tehnike su takođe razvijene tako da proizvode konstrukte sa različitim biopolimerima, koji se koriste u širokom spektru medicinskih implantata.

Skafoldi se takođe mogu izrađivati od granularnog materijala vezivanjem čestica rastvaračima ili lepkom, pri čemu se grade sloj po sloj. Takođe, skafoldi mogu biti izrađeni od prirodnih biopolimera i polisaharida kao što su želatin, dekstran i skrob. Mikroporozne strukture se mogu postići dodavanjem porogena i namakanjem čestica. Na primer, Simpson i sar. su proizveli porozni skafold od poli (mlečno-ko-glikolne) kiseline pomoću PFP-a i precizno reprodukovali oblik čitave falange ljudskog prsta [14]. Ove porozne strukture takođe su istražene sa aspekta vezivanja ćelija, rasta i depozicije matriksa.

Iako je PFP ograničen na praškaste materijale, njegova prednost je sposobnost izrade skafolda iz nekoliko materijala kao što su titanijum i magnezijum, koji se ne mogu lako štampati sa drugim tehnikama. PFP je posebno pogodan za koštane skafolde i skafolde drugih čvrstih tkiva jer vezani ili spojeni materijali stvaraju konstrukte superiornih mehaničkih svojstava. Osim toga, neki materijali koji se prirodno nalaze u kosti, kao što je trikalcijum-fosfat, takođe mogu biti odštampani korišćenjem PFP tehnika, omogućavajući stvaranje složenih oblika skafolda, uključujući unapred konstruisanu međusobno povezanu poroznost. Rezolucija i minimalna veličina pora ograničeni su karakteristikama praha, a dodatno sinterovanje je neophodno za očvršćavanje delova koji sadrže pukotine i druga oštećenja. Fokus tekućih istraživanja je na razvoju novih materijala za PFP i usavršavanju parametara štampanja radi poboljšanja površinskog dizajna skafolda.

\section{Fuziona depozicija}

FDM tehnike omogućavaju korisnu platformu za kreiranje skafolda pomoću preciznog xyz sistema pozicioniranja za usmeravanje položaja mlaznice prilikom nanošenja materijala [8, 15]. Materijal se deponuje u slojevima i učvršćuje u prethodno definisanom obliku. Tradicionalni SFF štampači često se koriste za brze prototipove korišćenjem akrilatril-butadien-stirena malog prečnika, koji se ubacuje kroz mlaznicu koja se zagreva do temperature veće od $200^{\circ} \mathrm{C}$.

Biorazgradivi polimeri koji se koriste $\mathrm{u}$ inženjerstvu tkiva uglavnom se rastvaraju na nižim temperaturama i mogu se odštampati na umerenijim temperaturama $\left(60-100^{\circ} \mathrm{C}\right)$. Korišćenjem ove metode moguće je proizvesti preciznu strukturu rešetke, ako se temperatura precizno kontroliše i optimizuje sa parametrima brzine tokom generacije filamenta sa potrebnom tačnošću. Novije generacije FDM sistema koriste zagrejan rezervoar za ekstruziju polimernih peleta umesto vlakana. Skafoldi dobijeni ovom tehnikom iz alginata i PCL implantirani u miševe pokazali su ubrzano formiranje hrskavice i kolagena četiri nedelje nakon implantacije [8].

Smanjenje veličine mlaznice i visine sloja povećava $\mathrm{x}-\mathrm{y}$ i z rezoluciju, što dovodi do znatno sporije brzine ekstruzije. Teorijska rezolucija je ograničena preciznošću linerano pokretnih sistema (motori, zupčanici, zupčasti kaiševi i navojne šipke) i retencionim svojstvima ekstrudiranog materijala. Iako FDM tehnike omogućavaju postizanje visokog stepena pozicione preciznosti u X-Y ravni, njihovo značajno ograničenje je u nemogućnosti štampanja visećih ili nepodržanih delova jer ne postoji potporni materijal iz prethodnih slojeva. Zbog toga je očvršćavanje tokom hlađenja ili unakrsno povezivanje nakon ekstruzije neophodno za zadovoljavajuću podršku sledećim slojevima. Takođe, ovaj nedostatak se može rešiti uvođenjem filamenta materijala za podršku tokom procesa štampanja, obično pomoću dodatnog ekstrudera (Slika 3).

Nedavna poboljšanja reoloških svojstava hidrogelova omogućila su štampanje ovih materijala pomoću FDM metode. Na primer, Hong sa sar. su napravili hidrogel koji se može štampati koristeći mrežu PEG i alginata sa silikatnim nanopločicama [16]. Ovi gelovi su posedovali nultu viskoznost iznad $10 \mathrm{kPa} \bullet \mathrm{s}$, što omogućava da zadrže oblik nakon štampanja i da se stanjuju pri smicanju, što olakšava ekstruziju. Veličina i tačnost štampanog konstrukta hidrogela zavise od zapremine sadržane u špricu i reoloških osobina hidrogela. Viskoznost igra ključnu ulogu u tačnosti konstruisanja, jer materijali visokog viskoziteta poseduju strukturnu rigidnost koja je važna za po- 
dršku ekstrudiranih uzastopnih slojeva, jer se sekundarni korak ukrštanja tipično koristi za zaključavanje štampanog oblika i za poboljšanje mehaničkih osobina ovih konstrukcija.

Štampači zasnovani na ekstruziji obično koriste pneumatski pritisak ili klip pokrenut motorom za nanošenje materijala. Pneumatski sistemi pojednostavljuju kontrolu primenjene sile na ekstrudirani materijal. Sistem treba kalibrisati za svaki materijal sa podešavanjem veličine mlaznice, geometrije mlaznice (koničnost vrha, cilindričnost igle i dužina) i pritiska gasa.

Izgleda da je FDM jedna od najsvestranijih tehnika štampanja za kreiranje biomimičnih skafolda zahvaljujući svojoj sposobnosti da napravi višeslojne konstrukcije izgrađene od različitih materijala i štampa mekane biomaterijale poput hidrogelova (Slika 4). Skafoldi štampani ovom tehnikom mogu pokazati anizotropne mehaničke osobine koje mogu biti korisne za proizvodnju skafolda sa namernim poravnanjem vlakana, kao što su ligament ili tetiva.

\section{Bioprinting}

Bioprinting pripada tehnikama aditivne štampe (ili aditivne proizvodnje) za kreaciju skafoda na bazi ćelija [17]. Ove tehnike su dominantno namenjene za štampu ćelijama istovremeno sa materijalom, budući da imaju minimalan uticaj na vijabilnost $i$ funkciju ćelija. Biološki materijali koišćeni za štampu bi trebalo da se podudaraju sa prirodnim okruženjem tkiva domaćina da bi podržali funkcionalnost ovih ćelija. Pritom, ćelije bi trebalo da budu u stanju da prevaziđu mehanički stres tokom procesa štampe i prežive njegove realno nefiziološke uslove [8].

Tehnike bioprintinga su klasifikovane u tri kategorije: mikroekstruzija, bioprinting uz pomoć lasera (LAB) i inkdžet bioprinting. Među njima, inkdžet bioprinting je tehnika koja najviše obećava u stvaranju složenih arhitektura, uspešno podražava nativna tkiva i organe. U inkdžet bioprintingu kapi „bio-mastila" se nanose na supstrat u obliku gela da formira polimernu strukturu, dok bioprinting mikroekstruzijom koristi mehanički ekstruder da nanese biomastilo. Bioprinting ekstruzija je koristan za veću gustinu ćelija, zbog lakše tehnologije izvođenja, ali je sporiji nego bioprinting kapljicama. LAB tehnika zahteva pikolitarsku (pL) rezoluciju, kroz koju se ćelije i tečni materijali mogu štampati. Ovaj metod štampe se brzo razvija i pokazuje se perspektivnim za proizvodnji tkivolikih struktura.

\section{Ekstruziono bio-štampanje}

Ekstruziono bio-štampanje je jedna od najekonomičnijih tehnika brzog prototipovanja (Slika 5) [8, 17]. Ekstruziono bio-štampanje tipično uključuje pritisak ili vijčano/klipno aktiviranje izlaska tečnosti koja sadrži ćelije i/ili biomaterijale. Trebalo bi da obezbedi istanjivanje i smicanjem omogući minimalni otpor pri protoku i brzu hemijsku ili fizičku unakrsnu vezu nakon ekstruzije, kako bi se podržali sukcesivni slojevi. Ova tehnika omogućava preciznu depoziciju materijala i izradu složenih struktura, uključujući i upotrebu više vrsta ćelija, omogućavajući na taj način ubrzani rast i formiranje novih tkiva. Poželjno je povećanje rezolucije štampanja i brzine štampanja. Pored toga, modifikacijom mehanike štampanja vreme štampanja se može smanjiti i može se postići koekstruzija više materijala. Glavni nedostatak je relativno dugo vreme izrade kako bi se postigla visoka rezolucija u kompleksnim strukturama. Ova metoda omogućava uspešnu izradu klinički relevantnih skafolda za tkivno inženjerstvo, jer je idealno prilagođena biološkim materijalima zahvaljujući svojoj sposobnosti da deponuje više materijala sa širokim opsegom svojstava. Skafoldi dobijeni ekstruzionim bio-štampanjem su obično mekani, zbog visokog sadržaja vode, što ih čini ograničenim za primenu samo kod mekih tkiva.

\section{Laserski potpomognuto bio-štampanje}

LAB, ili biološko lasersko štampanje, grupa je laserskih tehnika koje koriste lasersku energiju kako bi olakšale densifikaciju materijala skafolda (Slika 6) $[8,17]$. Jedan tip LAB-a podrazumeva upotrebu laserskog pulsa (LDV) za lokalno zagrevanje slajda sa slojem koji apsorbuje energiju i rastvorom ćelija. Laserski puls indukuje sublimaciju ili isparavanje materijala, proterujući rastvor ćelija na suprotnoj strani i precizno ih nanoseći na podlogu. Ova metoda uključuje laserski indukovani transfer i lasersko isparavanje pomoću matrice, koji se mogu koristiti za depoziciju fibroblasta, keratinocita, humanih mezenhimalnih matičnih ćelija, različitih kancerskih ćelija i biopolimera.

Kako laserske tehnike omogućavaju visoku preciznost, ova metoda je pogodna za bio-štampanje najmanjih detalja nativnih tkiva i organa. Ova tehnika pruža mogućnost direktnog štampanja ćelija, ali uz nekoliko ograničenja, kao što su štetan efekat na ćelijsko preživljavanje i njihovo dugoročno ponašanje.

\section{Inkdžet bio-štampanje}

Inkdžet bio-štampanje omogućava preciznu depoziciju ćelija i biomaterijala, koristeći neke pogodnosti 2D inkdžet štampanja kako bi nastali 3D skafoldi $[8,18]$. U ovom postupku ograničena zapremina tečnosti pada u precizan kalup kreiran pomoću odgovarajućeg softvera. Jedna od najvažnijih prednosti ove tehnike je brzina kojom se mogu proizvoditi skafoldi sa vrlo kompleksnom 3D arhitekturom. Ova velika brzina ograničava broj polimernih materijala koji se mogu koristiti za bio-štampanje, jer njihovo vreme geliranja mora biti veće ili jednako vremenu depozicije kapi.

Inkdžet bio-štampači se mogu prilagoditi za štampanje materijala sa povećanom rezolucijom i brzinom. Oni koriste termičku ili piezoelektričnu energiju da deponuju kapljice rastvora u željene kalupe i sastoje se od jedne ili više komora sa mastilom sa više mlaznica i sa odgovarajućim piezoelektričnim ili grejnim komponentama. Kratak impuls struje se koristi za aktiviranje komponente i izbacivanje kapljice mastila. U termičkim bio-štampačima često se javlja jak lokalni porast temperature, izazivajući stvaranje i pucanje mehurića, što dovodi do izbacivanja kapljica mastila na podlogu. U piezoelektričnoj inkdžet štampi, piezo-kristali indukuju povećanje pritiska, što dalje utiče na izbacivanje kapljice. Depozicija od mlaznice na površinu štampe se dešava kada električni naboj izaziva vibracije u kristalima, a vibracije se šire na površinu za štampanje. Pokazano je da toplotna i mehanička opterećenja pri termičkom bio-štampanju uzrokuju smanjenje vijabilnosti ćelija. Neki istraživači su koristili ovu metodu za štampanje retinalnih ganglija i glia ćelija izolovanih iz centralnog nervnog sistema odraslih bez negativnog uticaja na preživljavanje ćelija, dok su neki od njih uspeli da koriste termo osetljive gelove modifikovanjem kertridža komercijalno dostupnog inkdžet štampača za kreiranje višeslojnih skafolda [8]. 
Glavni nedostatak inkdžet štampanja je zahtev da biološki agensi budu u tečnom stanju, kako bi se omogućila depozicija. Odložene kaplijice zatim očvršćavaju u potrebnu geometriju, preko unakrsnog povezivanja na osnovu fizičkih, hemijskih, pH ili ultraljubičastih metoda. Zbog hemijskog unakrsnog povezivanja, mnogi prirodni materijali često menjaju svoje hemijske osobine. Osim toga, neki mehanizmi unakrsnog povezivanja indukuju smanjenje ćelijske vijabilnosti i funkcionalnosti (Slika 7).

Iako inkdžet bioprinting omogućava enkapsulaciju živih ćelija, njihova koncentracija mora da bude relativno niska da bi se omogućilo formiranje kapljice i sprečilo začepljenje dizne. Uprkos brojnim manama, ovaj metod ima veliki potencijal zbog svoje niske cene, visoke rezolucije i visoke kompatibilnosti sa mnogim biomaterijalima. Ovakvi štampači omogućavaju tačnu depoziciju finih kapljica precizne zapremine da bi stvorili skafolde visoke rezolucije sa netaknutim ćeijama. Veličina kapljica može biti podešavana između 1 i 300 pL sa brzinama depozicije od 1 do 10.000 kapljica u sekundi. Prema tome, ovaj metod omogućava stvaranje skafolda sa preciznošću od $100 \mu \mathrm{m}$, što je veoma obećavajuće za stvaranje složenih skafolda. Iako zbog tipičnih svojstava gel-mastila ne može proizvesti veoma visoke strukture, vrlo je pogodan za štampu kompleksnih tkivnih struktura sa velikom preciznošću zbog svoje sposobnosti da štampa više struktura i tipova ćelija.

\section{OČEKIVANA SUDBINA OVIH METODA U BUDUĆNOSTI}

Adaptacija postojećih metoda 3D štampanja za biološke primene je od ogromnog značaja za buduću proizvodnju tkivnih graf- tova i veštačkih organa. Pored inženjerstva tkiva, 3D štampanje se takođe koristi u oblasti isporuke lekova, analizi hemijskih i bioloških agenasa i organa na čipu uređaja [19].

Uprkos svom velikom potencijalu u regenerativnim strategijama, glavni izazovi se odnose na poboljšanje rezolucije, povećanje brzine i štampanja koje omogućava preživljavanje ćelija [18]. Tekući napori u unapređenju rezolucije štampanja u litografiji podrazumevaju razvoj metoda kao što su litografija elektronskim snopom i multifotonska apsorpciona polimerizacija, jer su ove metode pogodne za izradu skafolda sa veoma preciznom veličinom detalja, reda samo nekoliko desetina nanometara [20].

Materijali koji se koriste za 3D bio-štampanje moraju zadovoljiti sledeće kriterijume: treba da budu biokompatibilni, da podrže rast i diferencijaciju ćelija i da zadrže oblik dovoljno dugo da bi se očuvao integritet skafolda dok se ne završi proces očvršćavanja unutar geometrije skafolda. Najviše korišćeni materijali za ove svrhe su kolagen, želatin, hijaluronska kiselina, alginate, modifikovani kopolimeri i fotopolimerizujući makromeri [21].

Za dizajniranje kompleksnih skafolda koji imitiraju tkivo neophodna su dodatna istraživanja za tačno mapiranje kompleksnih tkiva da bi mogli da se naprave reproducibilni skafoldi sa zahtevanim strukturnim i biološkim osobinama. Jedan od glavnih izazova u budućem 3D štampanju je direktno bio-štampanje ili štampanje ćelija i biomaterijala direktno na pacijentu ili u pacijenta. Neke nedavne studije su pokazale mogućnost bio-štampanja direktno na rane ili opekotine [22]. Dalja unapređenja brzine štampanja i rezolucije su neophodna za in situ štampanje, koje će unaprediti regeneraciju tkiva i redukovati vreme oporavka pacijenta. 